\title{
COMBINATORIAL SET OF LEXICO-GRAMMATICAL CLASSES OF NOUNS IN THE RUSSIAN LANGUAGE
}

\author{
Mariya L. Lapteva \\ Astrakhan State University, Astrakhan, Russia \\ Natalya V. Lukina \\ Astrakhan State University, Astrakhan, Russia
}

\begin{abstract}
The article focuses on the changes of nouns, the lexico-grammatical features of which make it impossible to refer them to a specific lexico-grammatical class. The article is based on the assumption, that traditional methodological foundations, generally accepted in native language studies - the grammatical classification, according to which nouns belong to one of the four classes: concrete, abstract, collective or material nouns, - is rather conventional and doesn't cover many transitional phenomena observed in substantive lexis. The expansion of nominal semantic structure is often accompanied by grammatical shifts. Semantic structures of Russian substantives are described as apt to undergo six types of changes, which reflect combinatorics of lexical and grammatical categories of polysemantic nouns: concreteness - abstractness, concreteness - collectiveness, abstractness - concreteness, abstractness - collectiveness, collectiveness - abstractness, collectiveness concreteness. The considered polysemants demonstrate different lexico-grammatical features depending on the meaning in which they are used. The applied quantitative analysis has enabled the authors to conclude that the prevalent changes occur in nominal structures of abstraction - concreteness type, while the changes of collectivity abstraction type are less prominent in the Russian language. The article justifies the use of the term "lexicalgrammatical class" in relation to a lexical-semantic variant of the word, which refers to nouns by morphological characteristics.

Key words: noun, lexico-grammatical class, combinatorial set, concrete meaning, collective meaning, abstract meaning, material meaning.

Citation. Lapteva M.L., Lukina N.V. Combinatorial Set of Lexico-Grammatical Classes of Nouns in the Russian Language. Vestnik Volgogradskogo gosudarstvennogo universiteta. Seriya 2. Yazykoznanie [Science Journal of Volgograd State University. Linguistics], 2020, vol. 19, no. 3, pp. 27-37. (in Russian). DOI: https://doi.org/10.15688/ jvolsu2.2020.3.3
\end{abstract}

\section{КОМБИНАТОРИКА ЛЕКСИКО-ГРАММАТИЧЕСКИХ РАЗРЯДОВ ИМЕН СУЩЕСТВИТЕЛЬНЫХ В РУССКОМ ЯЗЫКЕ}

\author{
Мария Леонидовна Лаптева \\ Астраханский государственный университет, г. Астрахань, Россия \\ Наталья Владимировна Лукина \\ Астраханский государственный университет, г. Астрахань, Россия
}

Аннотация. В статье рассмотрены изменения имен существительных, лексико-грамматические осо-
бенности которых не позволяют отнести их к определенному лексико-грамматическому разряду. Утвержда-
ется, что принятая в отечественной лингвистике классификация лексико-грамматических разрядов суще-
ствительных, согласно которой субстантивы примыкают к одному из четырех классов: конкретным, отвле- 
ченным, собирательным или вещественным, - носит весьма условный характер и не затрагивает многие переходные явления, наблюдающиеся в субстантивной лексике. Расширение семантической структуры того или иного имени нередко сопровождается грамматическими сдвигами. В семантических структурах русских субстантивов авторами установлено шесть моделей изменений, отражающих комбинаторику лексико-грамматических разрядов многозначных существительных: конкретность - отвлеченность, конкретность - собирательность, отвлеченность - конкретность, отвлеченность - собирательность, собирательность - отвлеченность, собирательность - конкретность. Показано, что полисеманты обнаруживают разные лексико-грамматические особенности в зависимости от того, в каком лексическом значении употребляются. На основе количественных подсчетов определено, что доминируют изменения типа «отвлеченность - конкретность», в наименьшей степени проявляются изменения типа «собирательность - отвлеченность». Обоснована целесообразность использования термина «лексико-грамматический разряд» применительно к лексико-семантическому варианту слова, относящемуся по морфологической характеристике к существительным.

Ключевые слова: имя существительное, лексико-грамматический разряд, комбинаторика, конкретное значение, собирательное значение, отвлеченное значение, вещественное значение.

Цитирование. Лаптева М. Л., Лукина Н. В. Комбинаторика лексико-грамматических разрядов имен существительных в русском языке // Вестник Волгоградского государственного университета. Серия 2, Языкознание. - 2020. - T. 19, № 3. - C. 27-37. - DOI: https://doi.org/10.15688/jvolsu2.2020.3.3

\section{Введение}

Традиционным в русистике является деление классов слов на разряды в соответствии с общими лексическими и грамматическими признаками. Слова одного разряда характеризуются общностью функционирования в языке, схожестью в сочетательных и синтаксических возможностях. Слово, с одной стороны, подчиняется законам, которые диктуются принадлежностью к тому или иному разряду. С другой стороны, любое слово, будучи «живой» и активно функционирующей единицей, представляет собой отражение процессов, происходящих как в языке, так и в языковом сознании его носителей, способно «реагировать» на эти процессы, «приобретая» новые смыслы или даже новые значения. Возможные семантические изменения, которые могут происходить со словом, тем не менее не выходят за рамки системы, компонентом которой оно является.

Лексико-грамматическими разрядами считаются такие группы слов, которые выделяются в пределах одной части речи и характеризуются общностью или особенностью в проявлении грамматических категорий, присущих данной части речи. Общепринято деление имен существительных русского языка на следующие лексико-грамматические разряды: конкретные, абстрактные (отвлеченные), вещественные, собирательные (см.: [Бондарко, 2005; Виноградов, 1972; Козлова, 1999; Потебня, 1968; Радзиховская, 1997; Рус- ская грамматика, 1980; Трофимов, 1957; и др.]).

Однако, на наш взгляд, такая лексикограмматическая классификация имен существительных недостаточна и требует выделения переходных явлений, своего рода подгрупп имен, которые могут быть отнесены к разным лексико-грамматическим разрядам в зависимости от употребления в контексте. Имеются в виду случаи перехода имени существительного из одного разряда в другой при изменении лексического значения, а также случаи использования субстантива одного лексико-грамматического разряда в значении другого при употреблении слова в переносном значении. Цель настоящей статьи описать комбинаторику лексико-грамматических разрядов русских имен существительных, в семантической структуре которых на рубеже XX-XXI вв. произошли изменения. Такая цель обусловливает научную новизну проведенного исследования.

\section{Материал и методы исследования}

1. Методологической основой исследования послужили работы грамматистов середины и конца XX века. Ученые сходятся во мнении относительно конкретных имен существительных. Их признаки и сочетательные способности подробно описаны в работах Р.И. Аванесова и В.Н. Сидорова [1945], В.А. Трофимова [1957], А.А. Зализняка [1967], В.В. Виноградова [1972], Г.А. Золотовой, Н.К Онипенко, 
М.Ю. Сидоровой [2004], в «Русской грамматике» 1980 г. и «Русской грамматике» 1990 г. и др. Существительные, входящие в разряд конкретных, обозначают реальные предметы окружающей действительности, о чем писал еще Е. Курилович: «...если среди существительных конкретные имена нарицательные являются центральной семантической категорией, то это именно потому, что они обладают двумя способностями: значить (signifier) и обозначать (designer). У них есть определимое семантическое содержание, и в то же время они приложимы к реальным объектам» [Курилович, 1962, с. 251].

Конкретные имена существительные составляют нехарактеризованный разряд, поскольку не обнаруживают особенностей в проявлении свойственных данной части речи категорий рода, числа и падежа. В отличие от них абстрактные (отвлеченные), вещественные и собирательные имена формируют характеризованные разряды, поскольку обладают особенностями в отношении категории числа. Они либо не изменяются по числам, либо имеют форму одного из чисел - единственного или множественного. Например: бег, ходьба, мужество, хлопотьл, каникульи, выборы; сахар, сметана, мука, дрожжи, опилки, чернила; молодежь, студенчество, родня и др. [Радзиховская, 1997, с. 82].

Распределяя существительные по лексико-грамматическим разрядам, лингвисты руководствуются именно отношением субстантивов к категории числа. По этому признаку конкретные существительные противопоставлены остальным: они способны иметь форму единственного и множественного числа без изменения семантики, оппозиция «единственное - множественное» у этих слов имеет реальные основания, чего нельзя сказать о существительных других разрядов (см. работы В.В. Виноградова [1972], В.А. Плунгяна [2011], В.К. Радзиховской [1997], А.М. Чепасовой, И.Г. Казарчук [2012], а также «Русскую грамматику» [1980] и «Русскую грамматику» [1990]).

Иной взгляд на отнесенность существительных к тому или иному лексико-грамматическому разряду находим, например, в работах В.А. Трофимова: «Под грамматическою субстанцией разумеются все вещи и явления мира и вырабатываемые человеком понятия. Сообразно с этим намечаются две основные лексико-грамматические категории имен существительных: категория конкретности и категория абстрактности. Каждая из них, естественно, распадается на ряд входящих в нее более дробных категорий... В этот же раздел имен конкретных входит категория вещественности, то есть наименования, означающие вещество... Наконец, к конкретным именам относится и категория собирательности, то есть наименования, означающие совокупность живых существ: молодежь, студенчество, делегащия, войско...» [Трофимов, 1957, c. 14-15]. Таким образом, согласно представленной точке зрения, имена существительные можно разделить на два разряда - конкретные и абстрактные.

Несмотря на разницу в количестве лексико-грамматических разрядов имен существительных, ученые сходятся во мнении, что отнесение существительного к тому или иному разряду должно опираться на его лексическое значение. Так, Р.П. Козлова утверждает, что «определение состава того или иного разряда имен существительных должно зависеть в первую очередь от особенностей его денотата, а уж затем от грамматических категорий» [Козлова, 1999, с. 24]. Особенно это важно при анализе многозначных слов, поскольку в разных значениях слово может быть отнесено к разным разрядам. Так, в значении существительного лес обнаруживается собирательность (На солнце темный лес зардел), которая может как бы повторяться в нескольких единичных представлениях ( $A$ там пойдут леса...). Кроме того, обнаруживается вещественность (торговать лесом). Наконец, форма множественного числа леса применяется по отношению к строительному приспособлению, что свидетельствует о реализации значения собирательности (дом в строительных лесах).

В «Русской грамматике» 1980 г. говорится о случаях вариативного отнесения слова к тому или иному лексико-грамматическому разряду в зависимости от его значения. Особое внимание при этом уделяется вещественным именам существительным, которые могут иметь форму множественного числа, если обозначают не вещество, а его сорт, вид, тип. К таким существительным относятся, напри- 
мер, вино - вина, вода - водьр (минеральные), масло - масла, крупа - крупь, клей клеи и др. В этом случае вещественные существительные получают признаки конкретных существительных. Помимо этого, вещественные существительные во множественном числе могут употребляться для указания на массу, объем вещества, тогда они приобретают признаки собирательных имен существительных: вода - воды (мирового океана), песок - пески (пустыни), снег - снега (Урала) [Русская грамматика, 1980, т. I, c. 471$]$.

Выделение имен существительных в разряд собирательных и абстрактных происходит не только на основании лексических и грамматических признаков, но и на основании словообразовательных формантов. Так, В.В. Виноградов и авторы «Русской грамматики» 1980 г. отмечают суффиксы абстрактных и собирательных имен существительных: выносливость, заточка, темнота, новизна, синева, низина, разоружение, развитие, толкотня, упорство, формализм, ориентация, агентуpa, сырь [j-o], родня, учительство, кустарник, ивняк, старостат [Виноградов, 1972, c. 154; Русская грамматика, 1980 , т. I, с. 459460]. При этом мало внимания уделяется анализу вариативности этих существительных по отношению к лексико-грамматическому разряду. Об отвлеченных существительных говорится, что их семантика препятствует представлениям о счете, поэтому они имеют либо форму единственного числа, либо форму множественного числа: 1) ход, пение, мужество, глупость, ненависть, радость и 2) хлопоты, выборы, каникульи, переговоры. Некоторые из существительных первой группы могут образовывать формы множественного числа, но только в случае изменения лексического значения, когда речь идет о конкретных проявлениях отвлеченных качеств и действий. Ср.: чувство радости и маленькие радости, радости жизни (события, вызывающие радость); красота девушки и краcоты природы (красивые места) [Виноградов, 1972, с. 133].

Случаи возможного образования форм множественного числа собирательных существительных встречаем только в «Русской грамматике» 1980 г., где упоминается о неко- торых собирательных существительных, которые во множественном числе и, соответственно, в единственном числе называют устройства или конкретные множества: annapamypa - aпnаратуры (лабораторий), клавиатура - клавиатуры (органа). Однако при этом не отмечается вариативность отнесения слова к другому лексико-грамматическому разряду.

2. В исследовании нами учитываются переходные явления на морфолого-семантическом уровне. В области лексико-грамматических разрядов существительных они выделены в работах В.В. Бабайцевой [2000], Ю.П. Князева [2007], В.В. Лопатина [2007], В.А. Плунгяна [2011], А.М. Чепасовой и И.Г. Казарчук [2012] и др. Синергетическая система имен существительных, неоднозначных с точки зрения лексико-грамматической отнесенности, была описана Л.В. Калининой [2009] в аспекте языковой категоризации объектов действительности. С когнитивно-семасиологической точки зрения рассматриваемая проблематика представлена в исследованиях И.А. Мельчука [1998], Е.В. Падучевой [2004], В.А. Масловой [2006], а также Дж. Лакоффа [2004], L. Talmy [2000], A. Spencer [2002].

3. В статье описаны результаты функционально-грамматического анализа группы слов, изменения в семантической структуре которых произошли на рубеже XX-XXI веков. Зафиксированные в ходе исследования языкового материала модели лексико-грамматических колебаний характеризуют не функционирование словоформы в различного рода контекстах (на что обращалось внимание ранее), а разные лексико-семантические варианты многозначного слова.

Комбинаторика лексико-грамматических разрядов напрямую связана с изменениями, которые происходят в семантической структуре отдельных имен существительных. Динамичность, открытость, неравномерность лексико-семантической системы языка обусловливают наличие асимметричных подсистем, допускающих несогласованность элементов на отдельных «участках». Одним из лексикографических изданий, авторами которого была поставлена и удачно решена задача зафиксировать языковые изменения, является, на наш взгляд, «Толковый словарь русского 
языка конца XX века. Языковые изменения» под ред. Г.Н. Скляревской (далее - ТСРЯ), выбранный нами в качестве основного источника сбора языкового материала. Интенсивность семантических преобразований нашла отражение и в изменениях грамматических характеристик многих существительных.

Развитие семантической структуры слова влечет за собой изменение его лексикограмматических категорий. В результате анализа 107 лексических единиц нами были выделены типичные переходные явления, обусловленные тем, что существительное-полисемант в разных лексико-семантических вариантах либо слова-омонимы могут быть отнесены к разным лексико-грамматическим разрядам. Контексты употребления слова в том или ином лексико-семантическом варианте извлечены из Национального корпуса русского языка (далее - НКРЯ).

\section{Результаты и обсуждение}

\section{Конкретность - отвлеченность}

Лексико-грамматические изменения наблюдаются в процессе употребления имени существительного война, которое в конкретном значении ('вооруженная борьба между государствами или народами, между классами внутри государства') имеет форму множественного числа (региональные войны, развязаны войны), употребляется с количественными числительными (промел две войны), а в отвлеченном значении ('борьба, враждебные отношения с кем-чем-н.') не обладает таким грамматическим потенциалом (объявить войну с бездорожьем).

Отнесенность слов к разным лексикограмматическим разрядам нередко детерминирована и полным отсутствием семантических связей между значениями одного и того же звукоряда, то есть омонимией имен существительных. Ср.:

Акиия' - 'ценная бумага, выпускаемая обществом и дающая право на получение определенного дохода из прибылей акционерного общества'.

Акиия ${ }^{2}$ - 'действие, предпринимаемое для достижения какой-либо цели' (ТСРЯ, c. 45-46).
Лексическое значение второго омонима свидетельствует об отвлеченности имени, а его грамматика - о сохранении признаков конкретного существительного: оно имеет формы не только единственного, но и множественного числа (проводить акции протеста, организовать акции милосердия и т. п.).

По этой же модели развиваются существительные дайджест (ТСРЯ, с. 189), декларация (ТСРЯ, с. 193), криминал (ТСРЯ, с. 341-342), маятник (ТСРЯ, с. 378), мясорубка (ТСРЯ, с. 406), партия (ТСРЯ, с. 456), потолок (ТСРЯ, с. 483), почта (ТСРЯ, с. 485).

\section{Конкретность - собирательность}

Одну из регулярных моделей переноса значения в семантической структуре слова можно описать общей формулой «единичное совокупное» и в связи с этим выделить такой вид лексико-грамматических изменений, как «конкретность - собирательность». Ср.:

Альбом - '1. Тетрадь из плотных листов в переплете для рисунков, каких-л. коллекций, фотографий. 2. Собрание рисунков, репродукций, чертежей. 3. Несколько объединенных одним названием музыкальных произведений одного исполнителя или одного ансамбля (группы)' (Ожегов, с. 45-46). В данном случае представлен пример радиальной полисемии, при которой производные значения 2 и 3 развиваются на основе прямого: $1 \rightarrow 2,1 \rightarrow 3$. В ТСРЯ отмечается актуализация третьего значения (ТСРЯ, с. 47).

Эта модель реализуется, например, в семантической структуре существительного annapam, три лексико-семантических варианта которого ('совокупность органов, выполняющих какую-н. особую функцию организма', 'совокупность учреждений, обслуживающих какую-н. отрасль управления, хозяйства', 'совокупность сотрудников учреждения, организации какой-н. области управления') имеют собирательное значение, образованное на базе прямого конкретного - 'прибор, техническое устройство, приспособление' (ТСРЯ, с. 58).

Аналогичную модель лексико-грамматических изменений наблюдаем в семантической структуре следующих слов:

Архив - '1. Учреждение для хранения старых, старинных документов, документаль- 
ных материалов. 2. Отдел учреждения, где хранятся старые документы. 3. Собрание рукописей, писем' (Ожегов, с. 29). В ТСРЯ фиксируется еще одно значение, актуальное для области информатики, - 'данные, хранящиеся на диске в сжатом виде' (ТСРЯ, с. 61).

Банк - '1. Учреждение, осуществляющее финансовые действия с ценными бумагами и деньгами населения, предприятий, фирм; осуществляющее финансирование различных проектов, выдачу кредитов под проценты и т. п. 2. Систематизированное собрание материалов, веществ, сведений и т. п. для использования в исследовательских и практических целях’ (ТСРЯ, с. 73).

Бюджет - '1. Роспись доходов и расходов государства, региона, предприятия или отдельного лица на определенный срок. 2. Чьи-н. средства к существованию, доходы и расходы' (Ожегов, с. 66).

Эта модель реализуется в структуре существительных корзина (потребительская) (ТСРЯ, с. 333-334), кукла (ТСРЯ, c. 346), медь (ТСРЯ, с. 380), аналогично: золото, серебро.

\section{Отвлеченность - конкретность}

Языковой материал показывает, что в русском языке функционируют имена существительные, семантическая структура которых позволяет отнести их в прямом значении к отвлеченным, а в производно-номинативном - к конкретным. Например:

Реклама - '1. Оповещение различными способами для создания широкой известности, привлечения потребителей, зрителей. 2. Объявление с таким оповещением' (Ожегов, с. 675).

Баланс - '1. Соотношение каких-либо показателей, данных, цифр к определенному моменту времени. 2. Сводная таблица показателей состояния денежных средств предприятия' (ТСРЯ, с. 71).

Братство - '1. То же, что содружество, то есть взаимная дружба, дружеское единение. 2. Название некоторых монашеских орденов, религиозных организаций, обществ' (Ожегов, с. 58).

Видео - '1. Отрасль культуры (науки, техники, искусства, социальных отношений).
2. Видеофильм' (ТСРЯ, с. 135). При этом во втором значении существительное активно функционирует и как собирательное (любые видеозаписи).

В основе такого рода изменений лежит метонимический перенос, в частности по формуле «действие - результат действия». Сравним: существительное вклад, обозначающее опредмеченное действие по глаголу вкладывать / вложить (вносить / внести вклад в общее дело), и это же имя в значении 'денежные средства, помещенные в банк'. В первом случае имя существительное употреблено в отвлеченном значении, во втором - в конкретном.

Сложные семантические преобразования происходят и в семантической структуре существительных вылод и база. Субстантив вывод может употребляться в отвлеченном значении опредмеченного действия по глаголу вывести 'ведя, направить куда-н., удалить откуда-н.' (Ожегов, с. 110) (вывод войск из Афганистана) и в конкретном значении как дериват от этого же глагола в значении 'умозаключить, прийти к чему-н. на основе анализа' (Ожегов, с. 110) (у сочинения удачный вывод). Существительное база может выражать отвлеченное значение 'основание, основа чего-л.', конкретные значения 'опорный пункт вооруженных сил', 'учреждение, предприятие, склад, место хранения товаров' (Ожегов, с. 58) и собирательное значение 'в информатике совокупность данных, организованных в памяти компьютера по определенным правилам' (ТСРЯ, с. 68).

Эта модель реализуется в структуре существительных: дембель (ТСРЯ, с. 195), запись (ТСРЯ, с. 245), игра (ТСРЯ, с. 259), идея (ТСРЯ, с. 261), инъекиия (ТСРЯ, с. 277), колхоз (ТСРЯ, с. 306), лозунг (ТСРЯ, с. 363), презентаиия (ТСРЯ, с. 500), приход (ТСРЯ, c. 510), а также вера, душа, любовь, мечта, надежда, потеря, прием, призыв, приятность, радость, скромность, счастье, утрата, фантазия.

\section{Отвлеченность - собирательность}

Такой тип лексико-грамматической вариативности обнаруживается у существительного андеграунд (андерграуд), зафиксиро- 
М.Л. Лаптева, Н.В. Лукина. Комбинаторика лексико-грамматических разрядов имен существительных

ванного в словарях последних трех десятилетий (например, в ТСРЯ). Данное существительное вошло в язык одновременно в отвлеченном значении - 'нелегальное, отвергаемое официальной идеологией искусство' - и в собирательном значении - 'для называния всех тех, кто является создателями и приверженцами данного искусства' (ТСРЯ, с. 49). На основе формальных показателей данные значения в словарях не разграничиваются, поэтому только контекст позволяет отнести слово андеграунд к тому или иному лексикограмматическому разряду. Например:

(1) - Нас называли модным словом «андеграунд». Но по мне - последнее дело анализировать свою музыку и стихи. Просто где-то в мире этот самый андеграунд был игрой, а у нас это был стиль жизни нескольких поколений (НКРЯ. Емельяненко В. Андрей Макаревич: «Если лучшие годы проходят на зоне, ты будешь от нее в восторге» // Известия. 2002. 29 сент.).

В представленном контексте слово андеграунд употребляется дважды: в первом случае говорящий использует его для называния определенной группы лиц, к которой примыкал и он сам, то есть в собирательном значении, во втором случае - в отвлеченном значении стиля жизни.

Подобные языковые изменения можно отметить и у существительного архитекту$p a$, которое имеет не только отвлеченные значения ('искусство проектирования и строения зданий, сооружений зодчества' и 'стиль постройки'), но и собирательные: общеупотребительное ‘здания, сооружения' (Ожегов, с. 30) и терминологическое 'совокупность устройств, узлов, блоков компьютера или микропроцессора' (ТСРЯ, с. 62).

У существительного власть выделяется два отвлеченных значения: 'право и возможность распоряжаться чем-н., подчинять своей воле' (пользоваться властью) и 'политическое господство, государственное управление' (законодательная власть). Можно также говорить о значении собирательности у этого существительного в случае, когда оно (преимущественно в форме множественного числа) употребляется для называния лиц, облеченных правительственными, административными полномочиями: Власть(u) приняла(и) такое решение (Ожегов, с. 86).
Эта модель реализуется в структуре существительных демократура (ТСРЯ, с. 198), мир (ТСРЯ, с. 391), наличность (ТСРЯ, с. 408), операция (ТСРЯ, с. 437), план (ТСРЯ, с. 465), музыка (поп-музыка) (ТСРЯ, c. 476), аналогично: книга, театр, китч (кич) (ТСРЯ, с. 295).

\section{Собирательность - отвлеченность}

Данную модель лексико-грамматических колебаний представляет, например, существительное авангард, относящееся как в прямом, так и в переносном значении к собирательным: '1. Часть войск (или флота), находящаяся впереди главных сил. 2. Перен. Передовая, ведущая часть какой-н. общественной группы' (Ожегов, с. 16). Однако в ТСРЯ данное существительное отмечено в абстрактном значении - 'то же, что и авангардизм, общее название разных течений в искусстве 20 в., отходящих от реализма и ищущих новые формы художественного выражения' (ТСРЯ, с. 37). В НКРЯ зафиксировано большое количество контекстов употребления слова авангард в названном значении. Например:

(2) Краткий очерк Александра Якимовича «Русское искусство в XX веке» рассматривает революционный авангард, социалистический реализм и неофициальное искусство второй половины XX века в их развитии (НКРЯ. Кузин Максим. Красные пути. Об альманахе «Красные холмы» // Октябрь. 2001. № 2);

(3) Открытие Игр не оставило никаких сомнений. Это действительно был высочайший уровень: русская история не как местечковость, но как авангард мирового развития органично сочеталась с передовыми современными технологиями (НКРЯ. Больше чем тренировка // Эксперт. 2014. № 7 (886)).

Подобные лексико-грамматические колебания обнаруживаются в словах-омонимах актив" - 'наиболее деятельная, передовая часть какой-л. общественной организации, коллектива' и актив ${ }^{2}$ - 'часть баланса банка, предприятия, учреждения, включающая все виды материальных ценностей и денежных ресурсов' (ТСРЯ, с. 43). Омоним актив обладает признаками конкретного имени существительного, поскольку имеет соотносительные 
формы единственного и множественного числа: актив банка - активы банков и др.

Cр. также: вольница - '1. О группе людей, игнорирующих общепринятые нормы, правила поведения и т. п., не знающих разумных пределов в чем-л. 2. Об отсутствии ограничений в чем-л., разумных пределов и т. п.'. Второе значение впервые отмечено в ТСРЯ (ТСРЯ, с. 157).

Эта модель реализуется и в структуре существительных капитал (ТСРЯ, с. 284285), право (ТСРЯ, с. 488), синдром (ТСРЯ, с. 585), модерн (Ожегов, с. 361).

\section{Собирательность - кон кретность}

Примеров такого рода лексико-грамматических колебаний, по нашим наблюдениям, не много. Они зафиксированы, например, в структуре существительное валюта: в собирательном значении (только в единственном числе) - 'деньги какого-либо иностранного государства по отношению к деньгам данной страны' (платить валютой, купить за валюту, предпочитать валюту российским рублям и т. п.); в конкретном значении (изменяется по числам) - 'денежная единица какого-л. государства, лежащая в основе его денежной системы' (национальные валюты, валюты бывших советских республик, курcbl валют и т. п.) и 'о том, что дорого ценится, чем можно расплачиваться вместо денег' (Хлеб - валюта военного времени; Золото лучшая валюта и т. п.) (ТСРЯ, с. 120).

Такие же лексико-грамматические колебания, на наш взгляд, можно отметить у всех имен существительных, обозначающих денежные единицы: рубль, доллар, евро, франк, лира и др., в том числе и у самого существительного деньги. Ср.: Копейка рубль бережет и За проезд нужно заплатить двадиать рублей; Зарабатывать большие деньги и Взять деньги на проезд.

Эта модель лексико-грамматических колебаний реализуется и в структуре существительных канон (ТСРЯ, с. 284), кодекс (ТСРЯ, с. 301), коллектив (ТСРЯ, с. 303), компания (ТСРЯ, с. 315).

Количественные данные по описанным моделям изменений представлены в таблице.

\section{Выводы}

В статье выделены шесть моделей лексико-грамматических изменений в семантических структурах многозначных существительных русского языка: конкретность - отвлеченность, конкретность - собирательность, отвлеченность - конкретность, отвлеченность - собирательность, собирательность - отвлеченность, собирательность конкретность.

Наличие в русском языке комбинаторики лексико-грамматических разрядов имен существительных свидетельствует о богатом функциональном потенциале субстантивов. Расширение семантической структуры того или иного имени нередко сопровождается грамматическими сдвигами, что позволяет говорить о лексико-грамматических изменениях, самой активной моделью которых является употребление отвлеченных имен существительных в конкретном значении.

Зафиксированные языковые изменения, повидимому, свидетельствуют о том, что понятие

Модели лексико-грамматических колебаний имен существительных (в порядке убывания частотности)

Models of lexical and grammatical fluctuations of nouns (in descending order of frequency)

\begin{tabular}{|c|c|c|}
\hline $\begin{array}{c}\text { Модель лексико-грамматического } \\
\text { колебания }\end{array}$ & $\begin{array}{c}\text { Количество } \\
\text { единиц } \\
\end{array}$ & $\begin{array}{c}\text { Процентный } \\
\text { показатель }\end{array}$ \\
\hline Отвлеченность - конкретность & 43 & 40 \\
\hline Конкретность - отвлеченность & 19 & 18 \\
\hline Собирательность - конкретность & 15 & 14 \\
\hline Отвлеченность - собирательность & 13 & 12 \\
\hline Конкретность - собирательность & 10 & 9 \\
\hline Собирательность - отвлеченность & 7 & 7 \\
\hline Bcezo & 107 & 100 \\
\hline
\end{tabular}


«лексико-грамматический разряд》 следует использовать применительно не к слову или словоформе, а, скорее, к лексико-семантическому варианту, поскольку взятая вне контекста языковая единица - имя существительное - не может быть однозначно квалифицирована как выражающая конкретное / отвлеченное / собирательное / вещественное значение.

\section{СПИСОК ЛИТЕРАТУРЫ}

Аванесов Р. И., Сидоров В. Н., 1945. Очерк грамматики русского литературного языка. В 2 ч. Ч. 1. Фонетика и морфология. М. : Гос. учеб.-пед. изд-во Наркомпроса РСФСР. 234 с.

Бабайцева В. В., 2000. Явления переходности в грамматике русского языка. М. : Дрофа. 640 с.

Бондарко А. В., 2005. Теория морфологических категорий и аспектологические исследования. М. : Яз. слав. культур. 624 с.

Виноградов В. В., 1972. Русский язык : (Грамматическое учение о слове). М. : Высш. шк. $616 \mathrm{c}$.

Зализняк А. А., 1967. Русское именное словоизменение. М. : Наука. 372 с.

Золотова Г. А., Онипенко Н. К., Сидорова М. Ю., 2004. Коммуникативная грамматика русского языка. М. : Наука. 544 с.

Калинина Л. В., 2009. Лексико-грамматические разряды имен существительных как пересекающиеся классы слов: когнитивно-семасиологический анализ. Киров : ВятГГУ. 225 с.

Князев Ю. П., 2007. Грамматическая семантика : Русский язык в типологической перспективе. М. : Яз. слав. культур. 704 с.

Козлова Р. П., 1999. Лексико-грамматические разряды имен существительных в когнитивном аспекте // Вестник Тамбовского государственного университета. Серия: Гуманитарные науки. Вып. 1. С. 23-29.

Курилович Е., 1962. Очерки по лингвистике : сб. ст. М. : Изд-во иностр. лит. 456 с.

Лакофф Дж., 2004. Женщины, огонь и опасные вещи : Что категории языка говорят нам о мышлении. М. : Яз. слав. культуры. 793 с.

Лопатин В. В., 2007. Многогранное русское слово : Избранные статьи по русскому языку. М. : Азбуковник. $743 \mathrm{c}$.

Маслова В. А., 2006. Введение в когнитивную лингвистику. М. : Флинта : Наука. 296 с.

Мельчук И. А., 1998. Курс общей морфологии. В 4 т. Т. 2, ч. 2. Морфологические значения. М. : Яз. слав. культуры ; Вена : Кошелев. 545 с.

Падучева Е. В., 2004. Динамические модели в семантике лексики. М. : Яз. слав. культуры. 608 с.
Плунгян В. А., 2011. Введение в грамматическую семантику : Грамматические значения и грамматические системы языков мира. М. : Рос. гос. гуманитар. ун-т. $672 \mathrm{c.}$

Потебня А. А., 1968. Из записок по русской грамматике. В 4 т. Т. 3. Об изменении значения и заменах существительного. М. : Просвещение. $551 \mathrm{c}$.

Радзиховская В. К., 1997. К проблеме различения явлений лексико-грамматической разрядности и собственно грамматических явлений // Психолингвистика и современная логопедия : сб. науч. тр. / под ред. Л. Б. Халиловой. М. : Экономика. 304 с.

Русская грамматика. В 2 т. Т. I, 1980 / гл. ред. Н. Ю. Шведова. М. : Наука. 789 с.

Русская грамматика, 1990 / В. Н. Белоусов [и др.] ; под ред. Н. Ю. Шведовой, В. В. Лопатина. М. : Рус. яз. 639 c.

Трофимов В. А., 1957. Современный русский литературный язык : Морфология. М. : Изд-во Ленингр. ун-та. 286 с.

Чепасова А. М., Казарчук И. Г., 2012. Существительные в современном русском языке. М. : Флинта. 272 с.

Spencer A., 2002. Gender as an Inflectional Category // Journal of Linguistics. Vol. 38, iss. 2. P. 279-312.

Talmy L., 2000. Toward a Cognitive Semantics. In 2 vols. Vol. 2. Concept Structuring Systems. Cambridge (Mass.) ; L. : The MIT Press. 504 p.

\section{ИСТОЧНИКИ И СЛОВАРИ}

HКPЯ - Национальный корпус русского языка. URL: http://www.ruscorpora.ru.

Ожегов - Ожегов С. И., Шведова Н. Ю. Толковый словарь русского языка. М. : Азбуковник, $2000.944 \mathrm{c}$.

ТСРЯ - Толковый словарь русского языка конца XX века. Языковые изменения / под ред. Г. Н. Скляревской. СПб. : Фолио-Пресс, 1998. $700 \mathrm{c}$.

\section{REFERENCES}

Avanesov R.I., Sidorov V.N., 1945. Ocherk grammatiki russkogo literaturnogo yazyka. $\mathrm{V} 2 \mathrm{ch}$. Ch. 1. Fonetika i morfologiya [Essay on the Russian Literary Language Grammar. In 2 Parts. Part 1. Phonetics and Morphology]. Moscow, Gosudarstvennoe uchebno-pedagogicheskoe izd-vo Narkomprosa RSFSR. 234 p.

Babaytseva V.V., 2000. Yavleniya perekhodnosti v grammatike russkogo yazyka [Phenomena of 
Transitivity in the Grammar of the Russian Language]. Moscow, Drofa. $640 \mathrm{p}$.

Bondarko A.V., 2005. Teoriya morfologicheskikh kategoriy $i$ aspektologicheskie issledovaniya [Theory of Morphological Categories and Aspectological Studies]. Moscow, Yazyki slavyanskoy kultury Publ. $624 \mathrm{p}$.

Vinogradov V.V., 1972. Russkiy yazyk: (Grammaticheskoe uchenie o slove) [The Russian Language (Grammatical Theory of the Word)]. Moscow, Vysshaya shkola. 616 p.

Zaliznyak A.A., 1967. Russkoe imennoe slovoizmenenie [Russian Nominal Inflexion]. Moscow, Nauka Publ. 372 p.

Zolotova G.A., Onipenko N.K., Sidorova M.Yu., 2004. Kommunikativnaya grammatika russkogo yazy ka [Communicative Grammar of the Russian Language]. Moscow, Nauka Publ. 544 p.

Kalinina, L.V., 2009. Leksiko-grammaticheskie razryady imen sushchestvitelnykh kak peresekayushchiesya klassy slov: kognitivnosemasiologicheskiy analiz [Lexical and Grammatical Categories of Nouns as Intersecting Classes of Words. Cognitive-Semasiological Analysis]. Kirov, VyatGGU, 225 p.

Knyazev Yu.P., 2007. Grammaticheskaya semantika: Russkiy yazyk $v$ tipologicheskoy perspektive [Grammatical Semantics: Russian Language in a Typological Perspective]. Moscow, Yazyki slavyanskoy kultury Publ. 704 p.

Kozlova R.P., 1999. Leksiko-grammaticheskie razryady imen sushchestvitelnykh $\mathrm{v}$ kognitivnom aspekte [Lexico-Grammatical Categories of Nouns in the Cognitive Aspect]. Vestnik Tambovskogo gosudarstvennogo universiteta. Seriya: Gumanitarnye nauki [Tambov University Review. Series Humanities], iss. 1, pp. 23-29.

Kurilovich E., 1962. Ocherki po lingvistike: sb. st. [Essays on Linguistics. Collection of Articles]. Moscow, Izd-vo inostrannoy literatury. $456 \mathrm{p}$.

Lakoff J., 2004. Zhenshchiny, ogon i opasnye veshchi: Chto kategorii yazyka govoryat nam o myshlenii [Women, Fire and Dangerous Things: What Categories of Language Tell Us About Thinking]. Moscow, Yazyki slavyanskoy kultury Publ. $793 \mathrm{p}$.

Lopatin V.V., 2007. Mnogogrannoe russkoe slovo: Izbrannye statyi po russkomu yazyku [The Many-Sided Russian Word. Selected Articles on the Russian Language]. Moscow, Azbukovnik Publ. 743 p.

Maslova V.A., 2006. Vvedenie v kognitivnuyu lingvistiku [Introduction to Cognitive Linguistics]. Moscow, Flinta Publ., Nauka Publ. $296 \mathrm{p}$.
Melchuk I.A., 1998. Kurs obshchey morfologii. V $4 t$. T. 2, ch. 2. Morfologicheskie znacheniya [Course of General Morphology. In 4 Vols. Vol. 2 , Part 2. Morphological Meanings]. Moscow, Yazyki slavyanskoy kultury, Vienna, Koshelev Publ. 545 p.

Paducheva E.V., 2004. Dinamicheskie modeli v semantike leksiki [Dynamic Models in the Semantics of Vocabulary]. Moscow, Yazyki slavyanskoy kultury Publ. $608 \mathrm{p}$.

Plungyan V.A., 2011. Vvedenie v grammaticheskuyu semantiku: Grammaticheskie znacheniya $i$ grammaticheskie sistemy yazykov mira [Introduction to Grammatical Semantics: Grammatical Meanings and Grammatical Systems of World Languages]. Moscow, Rossiyskiy gosudarstvennyy gumanitarnyy universitet. $672 \mathrm{p}$.

Potebnya A.A., 1968. Iz zapisok po russkoy grammatike. V4 t. T. 3. Ob izmenenii znacheniya i zamenakh sushchestvitelnogo [From Notes on Russian Grammar. In 4 Vols. Vol. 3. On Changing the Meaning and Substitutions of the Noun]. Moscow, Prosveshchenie. 551 p.

Radzikhovskaya V.K., 1997. K probleme razlicheniya yavleniy leksiko-grammaticheskoy razryadnosti i sobstvenno grammaticheskikh yavleniy [To the Problem of Distinguishing Phenomena of LexicoGrammatical Depth and Proper Grammatical Phenomena]. Psikholingvistika i sovremennaya logopediya: sb. nauch. tr. [Psycholinguistics and Modern Speech and Language Pathology. Collection of Scientific Works]. Moscow, Ekonomika Publ. 304 p.

Shvedova N.Yu., ed., 1980. Russkaya grammatika. V 2 t. T. 1 [Russian Grammar. In 2 Vols. Vol. 1]. Moscow, Nauka Publ. 789 p.

Belousov V.N., Kovtunova I.I., Kruchinina I.N., Shvedova N.Yu., Lopatin V.V., eds., 1990. Russkaya grammatika [Russian Grammar]. Moscow, Russkiy yazyk Publ. 639 p.

Trofimov V.À., 1957. Sovremennyy russkiy literaturnyy yazyk: Morfologiya [Modern Russian Literary Language. Morphology]. Moscow, Izd-vo Leningradskogo universiteta. $286 \mathrm{p}$.

Chepasova A.M., Kazarchuk I.G., 2012. Sushchestvitelnye $v$ sovremennom russkom yazyke [Nouns in Modern Russian]. Moscow, Flinta Publ. $272 \mathrm{p}$.

Spencer A., 2002. Gender as an Inflectional Category. Journal of Linguistics, vol. 38, iss. 2, pp. 279-312.

Talmy L., 2000. Toward a Cognitive Semantics. In 2 vols. Vol. 2. Concept Structuring Systems. Cambridge (Mass.), L., The MIT Press. 504 p. 
М.Л. Лаптева, Н.В. Лукина. Комбинаторика лексико-грамматических разрядов имен существительных

\section{SOURCES AND DICTIONARIES}

Natsionalnyy korpus russkogo yazyka [Russian National Corpus]. URL: http://www.ruscorpora.ru. Ozhegov S.I., Shvedova N.Yu. Tolkovyy slovar russkogo yazyka [Explanatory Dictionary of the Russian Language]. Moscow, Azbukovnik Publ., 2000.944 p.
Sklyarevskaya G.N., ed. Tolkovyy slovar russkogo yazyka kontsa XX veka. Yazykovye izmeneniya [Explanatory Dictionary of the Russian Language of the Late $20^{\text {th }}$ Century. Language Changes]. Saint Petersburg, Folio-Press Publ., 1998.700 p.

\section{Information About the Authors}

Mariya L. Lapteva, Doctor of Sciences (Philology), Associate Professor, Professor, Department of Modern Russian, Astrakhan State University, Tatishcheva St., 20a, 414056 Astrakhan, Russia, hohlina2004@yandex.ru, https://orcid.org/0000-0003-2412-1299

Natalya V. Lukina, Candidate of Sciences (Philology), Associate Professor, Department of Modern Russian, Astrakhan State University, Tatishcheva St., 20a, 414056 Astrakhan, Russia, lukina.71@mail.ru, https://orcid.org/0000-0002-4518-0303

\section{Информация об авторах}

Мария Леонидовна Лаптева, доктор филологических наук, доцент, профессор кафедры современного русского языка, Астраханский государственный университет, ул. Татищева, 20a, 414056 г. Астрахань, Россия, hohlina2004@yandex.ru, https://orcid.org/0000-0003-2412-1299

Наталья Владимировна Лукина, кандидат филологических наук, доцент кафедры современного русского языка, Астраханский государственный университет, ул. Татищева, 20a, 414056 г. Астрахань, Россия, lukina.71@mail.ru, https://orcid.org/0000-0002-4518-0303 